\title{
THE IMPRISONMENT OF WOMEN IN GREEK TRAGEDY
}

IN Kreon's famous edict in Sophokles' Antigone the punishment for attending to the dead Polyneikes is death by public stoning (36). ${ }^{1}$ In the event, at the climax of his bitter argument with his son Haimon, who is betrothed to Antigone, Kreon threatens to have Antigone killed in front of Haimon's eyes (760-I). But when Haimon then angrily departs, Kreon orders Antigone to be imprisoned in a deserted place, underground in the rock, with a little food (773-5). Various motives have been suggested for this change of penalty, e.g. that the city may not want to cooperate in the stoning of Antigone. ${ }^{2}$ But the main factor must be the aptness of imprisonment underground for the specific case of Antigone. As Kreon himself ironically puts it, 'there she can ask Hades to save her from death, Hades who is the only god she reveres' (777-8). Imprisonment underground, in what is described as a tomb, suits the crime of one who has seemed too devoted to Hades, and produces the complementary inversions described by Teiresias (1068-7I): the dead Polyneikes is above the earth, while the living Antigone is below, in a tomb.

Another important symbolic role for the underground cell is as a bridal chamber. Antigone imagines it to be both a tomb and a bridal chamber (89I $\tilde{\omega}$ Túmßos, $\tilde{~}$ $\nu \cup \mu \varphi \varepsilon i ̃ v)$. And this is one of a series of respects in which her slow ${ }^{3}$ and elaborate departure evokes the association, from the real world of ritual, of the bridal with the funeral procession: in real life the bridal procession may be imagined as funereal, and the funcral procession of the unmarried girl as bridal. ${ }^{4}$ The theme is first suggested by Kreon himself, whose jibe that Antigone should marry in Hades $(654 ;$;f. 750, 76I) is eventually ironically fulfilled in the suicide of Haimon over the corpse of Antigone in her rocky chamber, in what the messenger calls 'wedding rites in the house of Hades' (I24I). But my concern in this paper is to detect another symbolic meaning of the enclosure of Antigone, namely the retention of a girl by her natal family at the expense of her sexual union with an outsider or marriage. It will also emerge that imprisonment of the female is in tragic myth generally associated with her link with blood-kin (as means of preserving it, punishment for over-valuing or breaking it - the narrative mechanism is of secondary importance), as one element in a complex of closely related themes: confinement, familial introversion, incest, darkness, blindness, and, at the opposite extreme to all that, the liberation provided by Dionysos.

When Antigone finally goes to her death, the chorus sing of various mythical paradigms ( $944 \mathrm{ff}$.): in the first strophe of Danae, hidden in a sepulchral chamber where she received the golden shower of Zeus; in the antistrophe of Lykourgos enclosed in rock by Dionysos; in the second strophe of the Phincidai, who were blinded by their stepmother; and in the second antistrophe of the girlhood of the Phineidai's natural mother Kleopatra. The precise relevance of these stories to the action of the play has been the subject of much discussion. The obvious points of similarity are very few: Danae was of noble blood and imprisoned; and Lykourgos was imprisoned in rock. And so a recent critic ${ }^{5}$ can write that the song 'looks forward to what is so familiar in Euripides, the use of ballad-like lyrics in which there is at times only a very tenuous

1 I would like to thank Su Braund and Helene Foley for their comments on an earlier draft, as well as discerning audiences at Oxford, Brown, Columbia, Yale, Berkeley, Santa Cruz, and UCLA.

2 B. M. W. Knox, The Heroic Temper (1964) 72. Less plausible motives are giving Antigone time to relent (Knox 72 , citing 888 , which is however surely rather an eschewal of responsibility: $f f .889$; in collective stoning there is no individual responsibility), and baulking at stoning a kinswoman (Jebb in his Commentary). See also H. D. F. Kitto, Form and Meaning in Drama (1956) I 66.

${ }^{3}$ Cf. 807 with 939 , and 932.

4 Seaford in JHS cvii (1987) 107.

5 R. W. B. Burton, The Chorus in Sophocles' Tragedies (1980) 132. The most recent discussion is by C. Sourvinou-Inwood in BICS xxxvi (1989). 
connection with the plot. It could indeed with very little alteration be made relevant to any character in any tragedy who is under sentence of death and who stands in need of exhortation before the stroke falls.' Others have compared various elements of the myths, some of them not actually mentioned in the song, with the action of the play: for example, the madness of Lykourgos (96I), and his consequent frenzied killing of his own son, might seem to allude to the 'madness' (765) of Kreon and the consequent loss of Haimon; or, it has been suggested, the reference to Kleopatra may foreshadow the death of Haimon's mother Eurydike. ${ }^{6}$ In favour of this approach it can be said that all three of the myths may well have been dramatised recently on the Attic stage, and so their details would be familiar to the audience of the Antigone. ${ }^{7}$ I am concerned neither to reject nor to defend these suggestions, but rather to detect running through the song a strand which, instead of requiring the chorus to foresee the future action of the play, emerges from what we imagine as happening simultaneously with the song, the imprisonment of Antigone in her bridal tomb.

This investigation will take us through a number of tragedies, and this will eventually allow us to see the relevance to Antigone of Lykourgos, the Phineidai, and Kleopatra. But we will start with Danae, whose story was dramatised by Sophokles and Euripides. She was, says our chorus, hidden and yoked in a sepulchral chamber $(946-7)$.

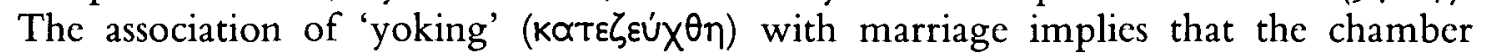
$(\theta \alpha \dot{\alpha} \alpha \mu \circ)$ is a bridal thalamos, in which Danae will of course be impregnated by Zeus. Both Danac and Antigone are at marriageable age deprived of marriage by being enclosed in a dark thalamos. The funereal associations of the normal wedding have for them become reality. Normally a girl is married, and the irreversible, frightening departure of the wedding is imagined as a funeral, or she dies before marriage, and her funcral is imagined as a wedding. But Danae and Antigone belong to a special, intermediate category. They are while still alive permanently enclosed. The bridal associations of the unmarried girl's tomb have become reality in that Danae and Antigone are still alive and will each suffer the irruption of a male into the chamber in a kind of wedding. But at the same time the tomb is a tomb, in that Danae and Antigone are intended to remain for ever in the dark isolation of their sepulchral confinement. 'Danae too', begin the chorus (944), 'left the light'; and in a more detailed contemporary Athenian account (by Pherekydes) Danae is imprisoned in a bronze chamber underground. ${ }^{8}$ Now although death and marriage may for the girl be envisaged in terms of cach other, as processional transitions from the natal family to a dark unknown thalamos, and so on, yet marriage is a means of continuing life, and so is in this respect antithetical to death. But Danae is sent living into her thalamos as a means of preventing offspring, in a kind of anti-wedding.

Antigone also, like Danae, owes her imprisonment (in place of marriage) in a bridal tomb to the power exercised over her by her natal family. There is of course an obvious difference. Whereas Danae is imprisoned by her father, Antigone's parents and brothers are all dead. However, her bond with them is particularly close. It is not only that, as she

${ }^{6}$ See esp. I. Errandonea in Mnem. li (1923) 180-201; Emerita xx (1952) I08-2 I; Sofokles (1958) 95-108; C. M. Bowra, Sophoclean tragedy (1944) $10_{4}$ f.; R. F. Goheen, The imagery of Sophocles' Antigone (I951) 64-74; G. Müller, Sophokles Antigone (1967) 213-8; R. P. Winnington-Ingram, Sophocles, an interpretation (1980) 98-109; C. Segal, Tragedy and civilisation: an interpretation of Sophocles (1981) 182-3.

7 Of surviving titles note S. Akrisios, Danae; E. Danae; A. Lykourgeia; Polyphrasmon Lykourgeia (467 BC); S. Phineus A, Phineus B, Tympanistai. And cf. my remarks below on the imprisonment of Klcopatra.

${ }^{8}$ FGH 3 F ro; Paus. ii 23.7 writes of an underground building over which was Danae's bronze thalamos; $c f$. also schol. Hom. Il. xiv 3I9; a whiteground lekythos published by I. Jucker in Antike Kunst Beiheft 7 (1970) 47-9 shows 'Akrisios' sitting on the tomb of 'Perseus'! of. S. Akrisios fr. 6I (Brein in $A A H G$ xxvii (1974) 249). Until about $760 \mathrm{BC}$ almost all children in Athens were inhumed within the family's domain, sometimes under the housefloor. 
says, her soul has long been dead, so as to help the dead (559-60). Near the beginning of the play she speaks of her eternal relationship in the next world with her brother in quasi-erotic language, which evokes the well-known association of the funeral bed with

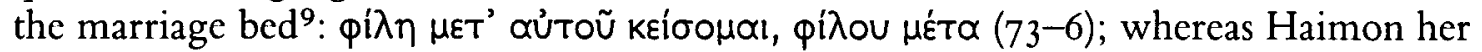
betrothed she never mentions (assuming that the manuscripts' and scholiast's attribution of line 572 to Ismene is correct, as recent opinion has increasingly held). In Euripides' Phoenician Women her explicit rejection of marriage with Haimon seems to be motivated by devotion to her dead brother (again expressed in quasi-erotic language ${ }^{10}$ ) and to her father (1679-8I). In a much later text this passes into an actually incestuous relationship with her brother. ${ }^{11}$ Incest is the rejection of marriage. It is in fact not only with her brother but with her natal family that, shortly before she moves off to her death, she looks forward to spending all eternity (Ant. $897 \mathrm{ff}$.) And so this processional departure is unique not only in that the funeral association of the normal bridal procession has become reality, but also in the following important respect.

In the wedding procession, as in the funeral procession of an unmarried girl, the girl is taken from her parental home to the power and the house of an unknown male (her husband, Hades). And so Antigone says that Hades is taking her off alive, and that she will marry Acheron $(8 \mathrm{I} 1,816)$. But in so far as she also stresses that she goes to join her natal family (897-9 'I hope to come dear to you, father, and dear to you, mother, and dear to you, brother'), the imaginary wedding procession is inverted, for in the normal wedding procession the girl takes permanent leave of her natal family. The funeral quality of the normal wedding procession is here amplified not only by the fact that Antigone will actually die, but also by the fact that for a girl to adhere permanently to her natal family is to deny the continuation of life through marriage.

There is a similar irony in the Sophoklean Elektra's complaint that, being unmarried, 'like a dishonoured stranger (ह̌TTolkos) I administer the chambers of my

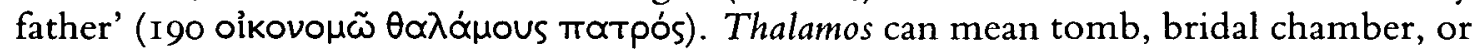
just the interior of a house. Here its primary reference is to the interior of the parental

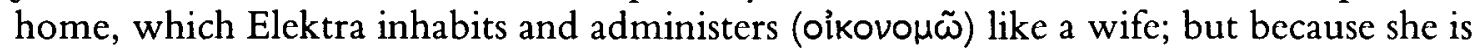
complaining of being deprived of marriage by her perpetual mourning, thalamos also connotes the bridal chamber and Agamemnon's tomb. ${ }^{12}$ And similarly the word $\alpha u \lambda \eta \dot{n}$ used in the Antigone (946) of the enclosure of Danae implicitly assimilates the enclosure of the sepulchral wedding chamber to the confinement of the unmarried girl in the dark interior of the female quarters within the walls ${ }^{13}$ of the parental $\alpha u ̛ \lambda \eta \dot{~ I n ~ P h e r e k y d e s ' ~}$ contemporary version Danae is imprisoned by her father in a bronze underground $\theta \alpha \dot{\lambda} \alpha \mu$ os within the $\alpha u \dot{\lambda} \lambda \dot{\eta}$ of his dwelling.

The unmarried girl moves, whether as bride or corpse, from one confined space to another. The pathos of Antigone's reversal of the normal direction of this movement is best expressed in lines 862-8: 'I am born', she says, 'from incestuous parents, to whom I

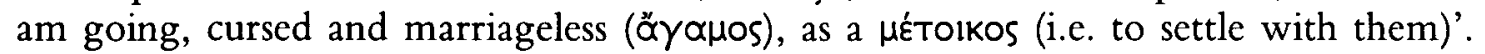
Note in passing firstly that she associates her parents' incest with her own adherence to them, ${ }^{14}$ and secondly that in the immediately following lines she laments the external

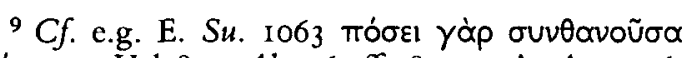

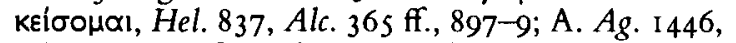
Cho. 904, 894 f. (with Garvie ad loc.); Anth. Pal. vii 604; W. Peek, Griechische Versinschriften I 1522; Ach. Tat. iii 1o. The ambiguity is exploited at S. Ant. 1224-5, 1240.

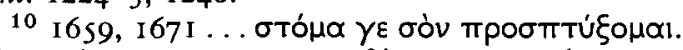

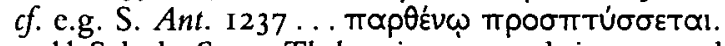

${ }_{11}$ Schol. Stat. Theb. xi $37 \mathrm{I}$, and in general G. Steiner, Antigones (1984) i 57 ff.

${ }^{12}$ Seaford in CQ $\operatorname{xxxv}(1985) 3$ I 8-19.
13 On female quarters in Classical Greek houses see Susan Walker in A. Cameron and A. Kuhrt (edd.), Images of women in antiquity (1983) 8I-9I.

${ }^{14}$ Cf. A. Sept. $\mathrm{IO}_{3} \mathrm{I}-2$ and S. Ant. SoI. Cf. modern case studies of the continuation of incest over generations: e.g. D. L. Raphling et al., 'Incest: a genealogical study', in Archives of General Psychiatry xvi (1967) s05; B. F. Steele and H. Alexander in Sexually abused children and their families (ed. P. B. Mrazek and C. H. Kempe, I98I) $230-1$. 
marriage made by her brother with the Argive princess which brought the invaders to Thebes. The two opposite extremes of incest and exogamy with a complete outsider

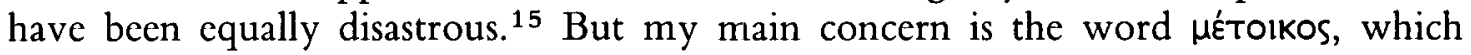

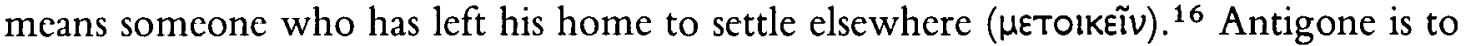
reside eternally with her natal family as an unmarried daughter; ${ }^{17}$ and yet, because she has to undertake a bridal-funeral journey to arrive there, she will be a metoikos, someone who has moved in, who in a sense does not belong, like the stranger, the epoikos Elektra claims to be in the thalamoi of her father. In this way the temporary isolation normal in bridal liminality, between the parental and the marital home, seems to be made permanent, ${ }^{18}$ and is associated, moreover, with the other respect in which Antigone suffers a unique intensification of liminal isolation, the liminality of the funeral: she has just used the very same word to describe her position, in the tomb but alive, as settled

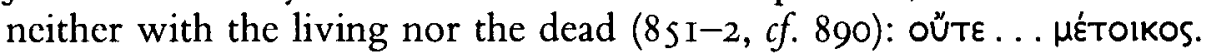

Our provisional conclusion, before we look at other tragedies, is that Antigone's fate is expressed in the strange compatibility of three incompatibles: marriage, attachment to natal family, and death. I will not enter the question of the authenticity of the famous lines $(904-20)$ in which Antigone, on the point of departure, says that what she did for a brother she would not have done for a husband or child, except to say that, whether authentic or not, they will be seen to cohere perfectly with this part of the play as I understand it. ${ }^{19}$

Sophokles' Elektra, like his Antigone, complains of being deprived of marriage and children. ${ }^{20}$ And in her case also, like Antigone's, this deprivation arises from her duty to her dead blood-kin. Her state of permanent lamentation for her father precludes marriage, and anyway she claims that Aigisthos would never allow her or Chrysothemis to produce offspring, who would be a danger to himself $(96 \mathrm{I}-6 ; c f$. E. El. 19-24). The association of sepulchral, bridal, and parental thalamos that we find in the Antigone is

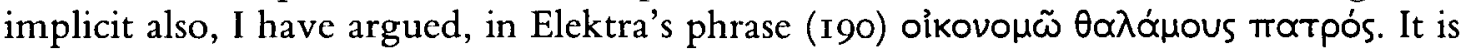
therefore highly appropriate that Elektra should be threatened with imprisonment in darkness: ${ }^{21}$ Chrysothemis says (379-82)

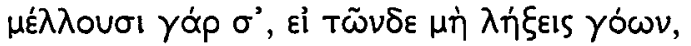

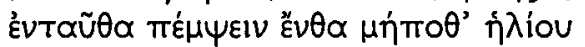

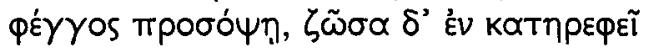

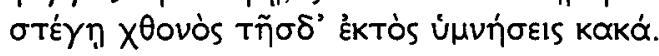

This passage presents a well-known textual problem. I have given the transmitted text, to which Kaibel rightly objects that the sunlessness mentioned requires an underground cell, and that it would be odd for the king to imprison Elektra outside the land he rules.

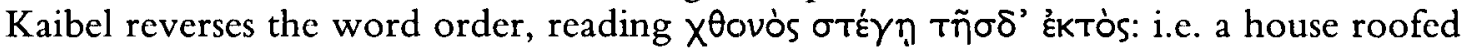
with the earth, outside this one, i.e. somewhere outside the palace. But we should rather change a single letter, to read हैvTòs. ${ }^{22}$ Elektra is to be put in an enclosed vault 'inside this earth'. The scribe may have been influenced by the later version, in which Elektra is sent

$15869-71$; of. 793-4 (in a hymeneal hymn to "Epws: Seaford in JHS cvii (1987) 108).

${ }^{16}$ As it does even at S. Ant. 890 (see Ellendt Lexicon Sophocleum).

17 Euripides' Kreon (Pho. I658) threatens to bury Antigone in the same grave as Polyneikes, and in the version preserved by Apollodoros (Bibl. iii 7.I) he actually does so.

18 Cf. Seaford (see n. I2) 3 I9.

19 Recent detailed discussions are by T. A. Szlezák in $R h M$ cxxiv (198I) 108-42 S. Murnaghan in AJP 107 (1986) 192-207. A. L.
Brown in his recent commentary fails to notice this coherence, and rejects the lines as 'rubbish'.

${ }^{20} \mathrm{El}$. 165, 961-2; of. Ant. 917-18.

21 If we suppose that the theme was borrowed from the Antigone, then this appropriateness helps to explain the borrowing.

22 Brought to this conclusion by consideration of the theme in general, I am reassured to find that it was arrived at presumably by a different route by Schenkel in the last century, albeit thereafter ignored. But I do not know what Schenkel took the passage to mean. 
out to a far corner of the kingdom, ${ }^{23}$ also perhaps by verse $39 \mathrm{I}$, in which Elektra regards the threatened imprisonment as allowing her 'to escape as far as possible from you' (i.e. from Chrysothemis as well as from Klytaimestra and Aigisthos): but this expression scems to me consistent with the separation of Elektra from the living, under the earth, as in a tomb, which she welcomes with the same almost maniacal bitterness that makes Antigone reject her sister's self-sacrifice, $(555,559$ f.) 'You have chosen to live, but I to die ... you live, but my soul has long been dead'.

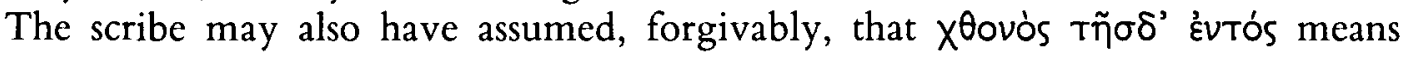
'within this land (sc. Mycenae).' In fact k̇vtòs generally implies being surrounded or concealed by the noun in the genitive, a shade of meaning better expressed perhaps by 'inside' than by 'within'. That is why évTós very often (especially in tragedy) means inside a dwelling, and why in the only case I have found of its meaning 'within the

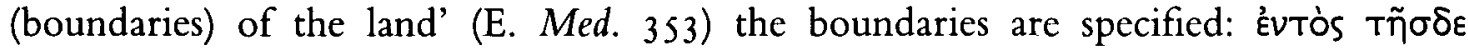

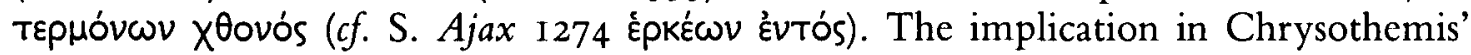

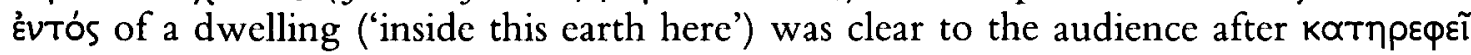

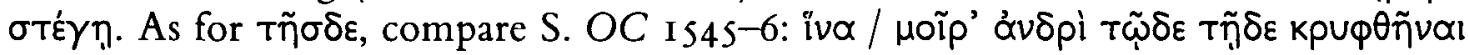
$\chi \ominus$ ovi. Oedipus intends to search the area for his 'tomb': the primary sense of $\chi \theta \omega$ ' material one-he is thinking of the earth somewhere nearby ( $\tau \tilde{n} \delta \varepsilon$ ) that will cover him

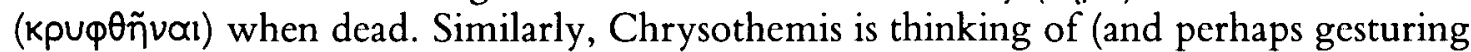
to) the earth on which she and Elektra are standing, and into which, somewhere nearby, Elektra is to be put as if dead. This is not to say that Oedipus' words do not have a secondary reference to Attica (for the soil of Colonus is Attic). This poignant combination of senses occurs elsewhere in Sophokles, ${ }^{24}$ which suggests that it may be (ironically) present even in $X^{\theta 0 \nu}$ òs $\tau \tilde{\eta} \sigma \delta^{\prime}$ '̇vTós here. But the main or only function of the phrase is to imply the unusual conjunction of dwelling and tomb that we find also in Antigone (89 I-2).

E้VTò restores antithetical point to the emphatically placed $\zeta \tilde{\omega} \sigma \alpha$. Elektra, deprived of marriage by her ritual duty to her dead kin, is to be confined living in a dark $\sigma \tau \varepsilon \dot{\gamma} \eta$, described as katnpeqn's, in the earth. Every one of these details is to be found also in the case of the Sophoklean Antigone. ${ }^{25}$ And just as Antigone is ironically told to go on worshipping Hades in her rocky tomb $(777-8)$, so Elektra is ironically told to go on with her wretched lamentation inside the earth. Danae, we saw, is also confined underground, but within her father's domestic space, his aủ $\lambda \eta$; and we shall find further examples of similar domestic confinement in due course. Klytaimestra and Aigisthos are most unlikely to want to send Elektra outside their kingdom; nor is this a feature of any version. They have in fact been trying to confine her within the house $(3+2-3,518-9)$, as she had been in Aeschylus' version during her father's death and funcral (Cho. 446-9). Elektra, unlike Antigone, is not betrothed. But Pacuvius' play, which is based no doubt on a Greek model, combined the wedding of Elektra, ${ }^{26}$ which presumably she resisted, with the threat to enclose her in darkness. ${ }^{27}$ And even in Seneca's Agamemnon Aigisthos' threat to imprison Elektra in darkness is expressed in the hymeneal metaphor of taming a frisky animal (I000 ut inquietam virginem carcer domet), like the 'yoking' of Danae in her thalamos in the Antigone.

The seclusion of a daughter, as a means of ensuring her chastity, occurs in numerous

${ }^{23}$ See E. El., and esp. Seneca $A g$. 997-1000 (even here she is not to be imprisoned outside the land); or perhaps Seneca was influenced by the corrupted text of Soph.

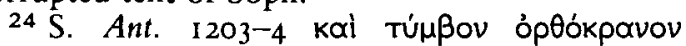

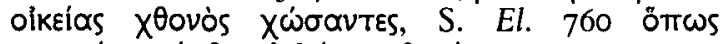

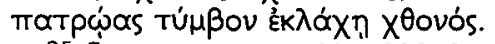

${ }^{25}$ See esp. vs. 774, 885, 888, 89I, 920, 944, I068,
I 100.

26 Presumably with Oiax: $\mathrm{O}$. Jahn in Hermes ii (I 867) 232. At A. Cho. 487 Elektra says that she will bring Xoòs $\gamma \alpha \mu \eta \lambda i$ ious to her dead father (i.e. at her marriage).

${ }^{27}$ Frr. I 19, 120-1, 131-2 Warmington (cf. fr. 125). 
myths and folktales world-wide listed by Stith Thompson ${ }^{28}$ and by J. G. Frazer, who associates it with the seclusion of girls in puberty rites. ${ }^{29}$ The seclusion must of course come to an end, even where the girl's family wants to make it permanent, as in the tragedies about Danae, and about Oinomaos, who presumably confined his daughter within the house-the door was, in Sophokles' version at least, ${ }^{30}$ decorated with the skulls of unsuccessful suitors. Somewhat different are those tragedies on myths in which a girl's natal family reasserts its control over her by imprisonment after her sexual union (usually with a god): Sophokles' Tyro, Euripides' Alope, Antiope, Auge, Melanippe the Wise, and Melanippe the Prisoner. Further, the story of Karya, who was guarded by her sisters against Dionysos renewing his amorous attentions (Serv. ad Verg. Ecl. viii 29) may well have been the theme of Pratinas' Dymainai or Karyatids. In various accounts ${ }^{\mathbf{3}}$ of the myth of the Danaids, Danaos told his daughters to murder their husbands and locked up Hypermestra when she failed to do so. This may have occurred in Aeschylus' version. The symbolic significance of enclosure is more obvious in the case of Arsinoc, who sided with her husband Alkmaion in his conflict with her brothers: the brothers reasserted their control over their sister by enclosing her in a chest (larnax) and taking her back to Tegea, where they gave her as a slave to an ally. The story was dramatised in Euripides' Alkmaion in Psophis.

By enclosing Arsinoe in a chest, her brothers can simultaneously impose the spatial confinement symbolic of a girl's subjection to her natal family and dispose of her (she has after all already left the natal home) in a place where she will be no threat to them. In Euripides' Alope (if, as is likely, it is reflected in Hyginus Fab. I87) king Kerkyon, discovering that his daughter Alope has secretly produced a son, orders her to be enclosed until she dies, and the son to be exposed (filiam iussit ad necem includi, infantem autem proici). From a remark of Pausanias ${ }^{32}$ we can infer that Alope was enclosed living in her tomb. Here the punishment of the unmarried daughter is an extreme form of the spatial confinement expressive of control by the natal family, whereas the male child, the potentially dangerous son of an outsider, suffers the opposite extreme of exposure in uncivilised, unbounded space. The combination of these opposites is allowed by the theme of enclosure in a mobile chest. After the failure of the enclosure of his daughter Danac under his domestic space, Akrisios encloses her again, this time in a chest, ${ }^{33}$ with her dangerous male child, and sends it to be carried far away into the unbounded space of the sea: enclosure is here combined with its opposite. In Euripides' Auge it appears that Auge's illicit union with Herakles was to be punished by her father with death, and that the punishment was eventually changed to exposure in a chest with her son in the sea.

We may allow ourselves here a brief detour, to Rome. A similar pattern, with some differences, is to be found in the story of the daughter of Numitor (Rhea Silvia or Ilia ${ }^{34}$ ), who was made a Vestal Virgin by her father's brother Amulius, because he feared that she might bear a son (to displace him). She is then raped by Mars (e.g. Livy i 4), or in one version by Amulius himself, ${ }^{35}$ and consequently (in some accounts) imprisoned

\footnotetext{
28 Motive-index of folk literature (I966) ns. T $38 \mathrm{I}$, 382.

29 The golden bough VII I, ch. 2. Cf. the father, 'hiding' his daughter in the shrine, after her 'licentiousness', in the aetrological myth of the puberty

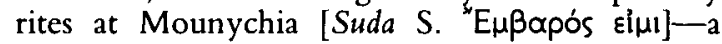
point I owe to Paula Perlman.

${ }^{30} \mathrm{fr} .473 \mathrm{a}$ R; Hygin. Fab. 84.

31 A pollod. Bibl. ii I.5; Ov. Her. xiv (esp. vs. 3 ff. clausa domo teneor); Hor. Odes. iii I I.45.

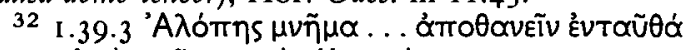
фабIV Úmó toũ matpòs Kepkuóvos.

${ }^{33}$ Pherekydes (n. 8 above) uses the word
}

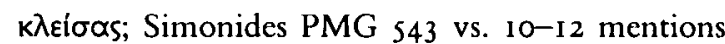
the bronze of the chest and the darkness within it: the larnax of the myth has a lid (LIMC s. Danae). A cruel variation on the theme is the story of Skylla, who after betraying her father to her lover is drowned by her father by being tied to the front of a ship (Apollod. Bibl. iii I 5.8;) TrGF vol. 2 (adesp.) F $8 \mathrm{~m})$.

${ }^{34}$ For Ilia as a Vestal Virgin sec Serv. Aen. vi 778 f.; Cic. De Div. i 20.40. For Rhea Silvia see refs. below.

35 D. H. A.R. i 77; Plut. Rom. 4 
by her uncle, ${ }^{36}$ and her sons Romulus and Remus are exposed. What makes this case particularly interesting is the existence of a related ritual. The Vestal Virgins perpetuate the hearth cult of the ancient royal household, in which they were envisaged either as the king's wives, or, much more likely I believe, his daughters. ${ }^{37}$ They are under the control of the Pontifex Maximus, who had inherited some of the powers of the early kings. ${ }^{38} \mathrm{He}$ presides over the famous punishment of the Vestals for sexual offences, ${ }^{39}$ which is strikingly similar to the Greek type best known from the Antigone: the offending virgin is taken in a funeral procession ${ }^{40}$ for permanent confinement in a cell in the earth equipped with a bed, a lamp, and some food ${ }^{41}$ ( $c f$. S. Ant. 807 ff., 774-5). What has happened here is that the paternal power to preserve the integrity of the royal household against the danger of the girl's sexual liaison with an outsider has devolved on the Pontifex Maximus, and this integrity has been transformed into a vital symbol, requiring if endangered extreme and spectacular confirmation, of the welfare of the entire state.

Then there is the story of Tennes, dramatised in a tragedy by Kritias or Euripides. ${ }^{42}$ Tennes is falsely accused by his amorous stepmother of making advances to her, with the result that his father encloses him in a chest ${ }^{43}$ and sends him out to sea. Now the combination of opposites inherent in enclosure in a chest in the sea takcs here a complicated form. It may be thought that restriction within a confined space is apt punishment for the over-closeness of the illicit sexual relation within the household that Tennes is suspected of; and indeed, when the wicked stepmother's lust for her stepson is

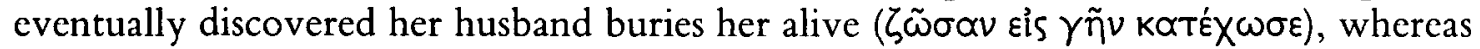
her accomplice is by contrast merely stoned. On the other hand, the father must remove the threat presented by his male offspring as far as he can from his household. After all, enclosure is generally for female kin, ${ }^{44}$ symbolically or actually separating them from outsiders. Hippolytus, in the same situation as Tennes, is exiled by his father, but not enclosed in a chest. The enclosure of Tennes, however, is dually determined, for he has a sister Hemithea, who joins him in the chest for no other reason than sympathy for her brother. They eventually come ashore at Tenedos, which they rule together (as if king and queen). We begin to suspect an excess of attachment between the siblings. And sure enough (though this does not seem to have been part of the play) Tennes is killed defending his sister against the amorous attentions of Achilles, whereupon Hemithea suffers the fate appropriate for excessive female adherence to male $\operatorname{kin}^{45}$ : she is swallowed up in the earth. ${ }^{46}$ Tennes and Hemithea deserve their place in an anonymous mythographer's list of $\phi 1 \lambda \dot{\alpha} \delta \varepsilon \lambda \phi \circ{ }^{47}$

36 Plut. Rom. 3; D. H. A.R. i 78 f.; Strabo v 3.2 (229); Livy i 4; Justin Epit. xliii 2.

${ }^{37}$ A recent discussion is by Mary Beard in JRS $\operatorname{lxx}(1980), 12-27$.

${ }^{38}$ Koch in $R E$ VIII $\mathrm{A}, 2$ I750 $\mathrm{f}$.

39 Plut. Numa Io; Plin. Ep. iv i I.6.

40 D. H. A.R. ii 67.4 ; Bömer in $R E \times x i, 2$ 1984 ff.; $f f$. Plut. Numa I I.6.

${ }^{41}$ Plut. Numa 10, Mor. 286 f; Cass. Dio ap. Zonar. vii 8.7. Athenians thought that their ancestors punished an unchaste daughter by walling her up in a house with a horse (Aesch i 182)-a point I owe to Victor Bers and to Adele Scafuro.

42 See most recently D. F. Sutton, Two lost plays of Euripides (New York I987) 85-7.

43 Konon (FGH $26 \mathrm{~F} \mathrm{I}$ ) says $\mathrm{k} \alpha \mathrm{T} \alpha \mathrm{k} \lambda \varepsilon i \varepsilon 1$, the

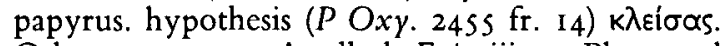
Other sources are Apollod. Epit. iii 24; Phot. and

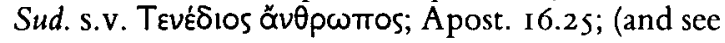

n. 42$)$.

44 The only examples known to me of a male enclosed by himself in a chest in the sea are (a) the incestuous Oedipus (Hygin. Fab. I6), (b) when the women take power at Lemnos (i.e. a myth of reversal) and Thoas is so treated by his daughter Hypsipyle: W. Burkert, Homo necans (English translation I983) 19I. Cf. also Adonis, offspring of an incestuous union, enclosed in a chest. Larissa punished her incestuous father Piasos by trapping him in a wine-jar (Nic. Damasc. fr. I9; Strabo xiii 3.4).

${ }^{45}$ And vice-versa: Poseidon buries his sons in the earth for raping their own mother (D.S. v 55.6-7).

46 Plut. Mor. 297 ef; Schol. and Tzetz. ad Lykophr. Alex. 232 ff.

47 Myth. Grace. Westermann i 345. 
In the Tennes myth enclosure in a chest or in the earth expresses or punishes the excessive closeness of illicit sexual relations within the household. An excessive bond between a girl and her natal family, and the enclosure which confirms or expresses it, may easily become in the mythic imagination incestuous. ${ }^{48}$ Oinomaos, for example, was hostile to his daughter's suitors because of, in one version, his incestuous passion for her. ${ }^{49}$ Even Danae is in one version sexually united in her underground chamber not with Zeus but with her father's brother Proitos. ${ }^{50}$ This is not of course an incestuous relationship: uncle-nicce marriage was common in fifth century Athens, but-or rather because-it is endogamous, the girl being retained within the houschold of her grandfather. An interesting case is Antiope, whose story was dramatised by Euripides. ${ }^{51}$ After her sexual union with Zeus, she escaped from the threats of her father, but was recaptured (after the suicide of her father) by his brother Lykos, who was also said to have been sexually united with her. This is suspected by Lykos' wife Dirke, who consequently has Antiope imprisoned in darkness (Hyginus Fab. $7 \ldots$ in tenebris vinctam clauderent; Propertius' account also refers both to her sex with Lykos and to the darkness of her imprisonment: iii I5.12, I7). In Pacuvius' tragedy at least Antiope seems to have described at length the sufferings of her imprisonment. ${ }^{52}$

Now a number of myths associate father-daughter incest with darkness in ways and with an emphasis that can be explained neither by the need of one of the partncrs to deceive nor by the secrecy appropriate to illicit sex (sometimes described as 'dark') in general. It is at night that Thyestes rapes Pelopia, who unknown to him is his daughter (compressio nocturna, - the story is told in Hyginus Fab. 88, which is generally belicved to derive from Sophokles' Thyestes in Sikyon); and it is in a moonless, starless night that Myrrha is united with her father Kinyras. ${ }^{53}$ Kyanippos, Plutarch tells us (Mor. $3 \mathrm{IOb}$ ), drunkenly raped his daughter Kyane 'in a dark place'. The adjective kUáveos, or KUavoũs 'dark', can be used of e.g. Hades or the thalamos of Persephone (see LSJ); and so the name Kyane is of the same type as Nyktaia, the 'night girl', who was sexually united with her father, who is variously Nykteus or Proitos (Lact. Plac. ad Stat. Theb. iii 507). Antiope herself is sometimes called 'Nykteis' after her father Nykteus. ${ }^{54}$ And Nyktimene, after sex with her father Epopeus or 'Nykteus', sought out darkness to conceal her shame. ${ }^{55}$ Whether envisaged as expressing, punishing, or concealing the shame of incest, darkness is an apt symbol for a shameful union within the enclosed secrecy of the natal family. ${ }^{56}$

This symbolic role of darkness may help to add a dimension missing from the discussion of the theme of blindness in Greek myth. George Devercux ${ }^{57}$ lists numerous myths in which blindness follows a sexual offence, arguing in explanation that the 'Greek data confirm the clinical finding that the eyes tend to symbolise the male organs, and blinding castration;' whereas Richard Buxton, ${ }^{58}$ preferring structure to psychoanalysis, tentatively explains these cases of sexual blindness within a general analysis of blindness as imposed for transgressing the limits between man and god: 'in

\footnotetext{
${ }^{48}$ For an ethnographic example of enclosure in the parental home as a symbol of incest see C. LéviStrauss, The raw and the cooked (translated 1970) 64. Edith Hall draws my attention to Genesis 19.30-8, where Lot commits incest with his daughters in the unusual location of a cave.

49 A pollod. Epit. ii 4; Hygin. Fab. 253.

50 A pollod. Bibl. ii 4. I; Pi. fr. $248 \mathrm{Sn}$.

$51 \mathrm{~J}$. Kambitsis, L'Antiope d'Euripide (Athens I972): main sources for the myth are schol. A.R. iv 1090; A pollod. Bibl. iii 5.5; Hygin. Fab. 7 and 8; Anth. Pal. iii 7; Propert. iii I5. I 1-42.

52 Frr. 13-4, 23-5 Warmington (with fr. $25 \mathrm{cf}$. A.R. 4.1095).
}

53 The stress in Ovid's account (Met. vi) on the uncanny darkness gous well beyond the needs of deceiving Cinyras: note esp. the association of darkness and shame at 448-5I and 454-6.

54 e.g. Ov. Met. vi I I ; of. Apollod. Bibl. iii 5.5.

55 Hygin. Fab. 204; Ov. Met. ii 590 ff.; Serv. Georg. i 403; Mythogr. Vatican. i 98; ii 39; for darkness and shame $f f . n$. 53 above.

${ }^{56}$ It is perhaps worth adding that illicit sex at nocturnal festivals includes brother-sister incest: Ps.

Plut. De Fluv. vii 2; I7.1; 21 .

57 JHS xciii (1973), 36-49.

58 JHS C (I980), 22-37. 
ignoring the restrictions placed on human sexual conduct, the transgressor is occupying a territory of greater freedom of sexual relationships normally available only to the gods.' But more to the point, perhaps, is that the well-known function of the eyes as a channel of erotic passion ${ }^{59}$ is always potentially transgressive of limits within the human sphere. Most of Devereux' mythical examples are of sex with an outsider (adultery, unfaithfulness, rape, etc.). Now in one case a girl (Amphissa or Metope) is in fact not only blinded by her father for having sex with a man but also put in a 'dark hut' (A.R. iv 1095). Similarly, Melanippe (an example missed by Devereux) is, as a result of producing a son by Poseidon, both blinded and imprisoned with a small amount of food and drink in a tomb by her father Desmontes (Hyginus Fab. I86: in munimento is very odd; read in monimento). The father symbolically reasserts his control over his daughter by re-enclosing her, punitively, in the darkness of enclosure and the darkness of blindness. The danger presented by a son, on the other hand, is a liaison with his father's sexual partner. Of the examples listed by Devereux of blinding following sex with an insider, a member of the same household, all but one are of a son with his father's wife or concubine. To his list we may add the anonymous Attic youth who, having rejected the advances of his father's concubine, was accused by her of making advances and consequently both blinded and imprisoned by his father (it is also significant that the concubine ended up deep in the earth, by throwing herself into a well). ${ }^{60}$ Darkness, we have argued, is associated in myth specifically with incest, whether as a punishment of the act or as concealment of its shame. And so blinding is as a consequence of incest doubly appropriate, as removing the ocular channel of illicit passion but also, antithetically, as expressing its enclosed introversion.

Let us return to the story of Antiope. ${ }^{61}$ After mating with Zeus she escapes from her father and comes to a place where (as Hyginus puts it) Epaphos of Sikyon happened to be, and he took her back to his home as wife. Her father Nykteus then killed himself in despair. At some stage she gave birth to Zeus' sons Zethos and Amphion, who were brought up on Mt. Kithairon. Recaptured from Sikyon by her amorous uncle Lykos, she is imprisoned but then escapes again to the mountainside. The story moves between the two opposite extremes of over-control of female kin (enclosure, and incest) and disastrous loss of control (to Zeus, and to Epaphos). This opposition has its spatial dimension in the polarity between domestic confinement at the centre and the dangerous, peripheral mountainside. There is also a Dionysiac dimension. Euripides' play was set near the border with Attica, at the cave in which Antiope had been raped by Zeus in the form of a satyr, and which seems to have been sacred to Dionysos. ${ }^{62}$ At the same cave Antiope gave birth to her sons and gave them to the slave of Oineus, the 'wine-man'. ${ }^{63}$ We know from Apollodorus (Bibl. iii 5.5) that when Antiope escaped from captivity to the mountainside her chains fell away automatically ( $\tau \tilde{\omega} \nu \delta \varepsilon \sigma \mu \tilde{\omega} \nu$

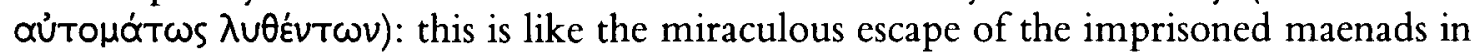

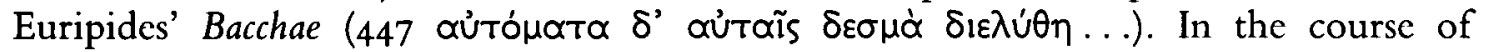
Euripides' Antiope it appears that Lykos' wife Dirke came to the cave as part of a band of maenads. According to Pausanias (ix I7.6) Antiope herself was driven mad by Dionysos and roamed all over Greece.

Of the two poles by which the myth of Antiope is structured the external one seems to belong to Dionysos. Dionysos, of course, extracts girls and women from the

59 There is an example in S. Ant. itself (795); cf. also A. Ag. 742 ; S. frr. 157, 474 (Pelops and Hippodameia); etc.

${ }_{60}$ Hieron. Rhod. ap Suda s. 'Avarupáólos.

${ }^{61}$ See above n. SI for refs. For the detail on which the following argument about Dionysos is based see Seaford in JHS cviii (1988) I 1 8-36.

${ }^{62}$ Frr. $179,203 \mathrm{~N}^{2}$; T. B. L. Webster, The tragedies of Euripides (1967) 205-6.

${ }^{63}$ Dio Chrys. xv 9 (ii 234 Arn.); $c$. E. fr. ${ }_{179} \mathrm{~N}^{2}$. 
enclosure ${ }^{64}$ of their homes to set them dancing on the mountainside. King Proitos, for example, whom we have twice caught having sex with his own kin, lost his daughters in this way; and Ovid makes a tantalisingly brief mention of Danae's father Akrisios' exclusion of Dionysos from his city (Met. iv $607 \mathrm{ff}$.; also iii $559 \mathrm{f}$.). Pentheus' repeated fear of Dionysos as an erotic danger to the Theban maenads is certainly justified by Dionysos' other appearances in myth and ritual, ${ }^{65}$ if not by what happens in the Bacchae itself. Pentheus imprisons some of the maenads, and threatens to imprison the others $(226-32,443-7$, SII-4). The theme of imprisonment of the maenads was, it appears, more prominent in Aeschylus' version of Lykourgos' resistance to Dionysos. ${ }^{66}$ In the various accounts of the myth Lykourgos is punished in various ways: he is driven mad, kills his offspring, attempts incest with his mother, cuts off his own foot, kills himself, is torn apart, is blinded, is imprisoned in a cave. ${ }^{67}$ We cannot know which of these occurred in Aeschylus' version. ${ }^{68}$ Certainly, they almost all represent a common tendency: Lykourgos is cut off from the outside, turned violently in on himself or his family. Whereas the women enclosed against the power of the stranger god are set free, the man who encloses is himself subjected to violent forms of enclosure and introversion. Perhaps it is no accident that one account makes Lykourgos the father of Antiope. ${ }^{69}$

Under the influence of Dionysos people tend to kill their own kin, and this may arise from either of two opposite extremes: on the one hand, for the resisting women, disastrous liberation from male control and frenzy on the mountainside (Agaue, the daughters of Minyas, the women of Argos, etc.); on the other hand, for the resisting men disastrous introversion, as with Lykourgos, but also e.g. the cases reported by Plutarch (Mor. $3 \mathrm{Iob}-\mathrm{c}$ ) of Kyanippos and Aruntius, each of whom resists Dionysos and in consequence drunkenly rapes and is killed by his own daughter. The safe, middle way between the two extremes of excessive control of the female and complete loss of control is to be found in ritual, in the controlled, temporary ceding by the Athenian 'king' (the archon called basileus) of his wife for the sacred marriage to the newly arrived Dionysos at the Anthesteria, which has a mythical analogue in the similar act of prudent generosity by king Oincus of Kalydon.

I conclude this digression into the sphere of Dionysos with a mention of three lost tragedies which seem to have embodied the catastrophic polarity we have identified between Dionysiac liberation and the excessive confinement of the female. Pratinas' Dymainai or Karyatids may well have been about Karya, who was imprisoned by her sisters against the amorous intentions of Dionysos. As a result, Dionysos sent the sisters in a frenzy to the mountainside, where he turned them into barren stones and Karya into a nut tree (Serv. ad Verg. Ecl. viii 29). Secondly, in Sophokles' Tereus ${ }^{70}$ it appears that after being raped and having her tongue cut out by her brother-in-law Tereus, Philomela has been imprisoned on the mountainside; in the course of the play it seems that Philomela's sister, Tereus' wife Prokne, takes the opportunity during a Dionysiac festival to go as a maenad out to where Philomela is imprisoned, liberates her, dresses her too as a maenad, and brings her back to the palace, where Prokne inflicts on her husband

${ }^{64}$ e.g. E. Ba. 36 (and of. 38 with 33 ); C. Segal, Dionysiac poetics and Euripides' Bacchae (Princeton I982) ch. 4; Anton. Lib. Met. Io; etc.

65 Seaford in JHS cviii (1988) $125-6$.

66 The imprisonment seems introduced into $E$. $B a$. as a traditional element (Dodds ad $443^{-8}$ ); and cf. Apollod. Bibl. iii s.1; Naevius fr. 46 Warmington; Dodds' Introduction xxxii $f$.

67 A pollod Bibl. iii 5.1; Hygin. Fab. 132, 242; Serv. Aen. iii 14; Ov. Fasti iii 722; schol. Lucan i 575; D. F. Sutton in $R S C$ xxiii (1975) 356-9; etc. ${ }^{68}$ Fundamental discussion of the trilogy: $\mathrm{K}$. Deichgräber, Gött. Nachr. 1938/9, I (3) 23 I-309. A recent account: M. L. West in BICS xxx (I983), $63 \mathrm{ff}$.

${ }^{69}$ Kypria, p. 31.36-7 Davies; Lykourgos as Theban king: $R E$ xiii 2433.

${ }^{70} \mathrm{~A}$. Kiso, The lost Sophocles ch. 3; note esp. Ov. Met. vi 422-676; Accius fr. 647 Warmington. 
the introverted horror of endocannibalism, the eating of their son. And thirdly, in Euripides' play Ino Athamas, after marrying Themisto, discovers his first wife, Ino, whom he had imagined dead, as a maenad on Mt. Parnassos; he brings her back and conceals her as a captive in his house, with the eventual result that Themisto kills her own children and then herself, and Athamas kills one of his children by Ino and Ino jumps into the sea with the other. ${ }^{71}$

To return to the Antigone: the complex of relationships we have discovered in tragic myth between imprisonment, the natal family, darkness, blindness, incest, and Dionysos illuminates in ways too numerous to spell out here the problem of the mythical paradigms in verses 944-87. From Danae, where we left them, the chorus move on to

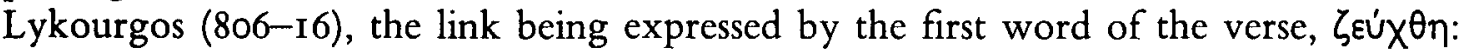
they were both 'yoked' (imprisoned). About the introversion of Lykourgos enough has been said earlier. I will add only that if, as Martin West suggests, Aeschylus' Edonians ended with the departure of Lykourgos for his rocky confinement, this would parallel the departure of Antigone just witnessed by the audience. ${ }^{72}$ As for the story of the Phineidai and their mother Kleopatra that takes up the second two verses of the ode, the chorus end with the words 'against her too' (i.e. against Kleopatra) 'the Fates bore hard.' But what is the point of similarity between Kleopatra and Antigone? Kleopatra married Phineus, by whom she had two sons. In the version referred to here the sons are blinded by Phineus' second wife; elsewhere we discover the stepmother's motive: it is the wellknown theme of the amorous stepmother, rebuffed by her stepson, persuading her husband that it is she who has suffered the sexual advances. ${ }^{73}$ But what happened to Kleopatra? The only suffering of hers that we ever hear of is imprisonment; and although this is in a much later text (D.S. iv 44.3), it is surely this imprisonment that Sophocles has in mind here. ${ }^{74} \mathrm{He}$ does not need to specify it, partly perhaps because one or more of his own dramatisations of the myth (see n. 7) may have been fresh in the audience's memory. ${ }^{75}$ But why should he spend on the blinding of Kleopatra's sons a whole antistrophe, as much as he does on Danae, on Lykourgos, on Kleopatra? One part of the answer is in the equivalence of imprisonment and blinding as forms of the enclosed darkness associated with familial introversion: the young men are blinded because suspected of introverted sex, with their stepmother. ${ }^{76}$ In some accounts, indeed, they are imprisoned. In the report of Kleopatra's imprisonment her sons are also confined, apparently in a burial vault. ${ }^{77}$ And the scholiast on this passage of Antigone tells us that it was after the death of their mother that they were confined in a tomb (perhaps hers?). This confinement does not occur in the Sophoklean song, just as, conversely, Lykourgos, who tried to rape his mother and was blinded, has only his confinement mentioned in the Sophoklean song.

Another part of the explanation of the strange emphasis and omissions in the account

${ }^{71}$ Hygin. Fab. 4 'Ino Euripidis'; $c f$. Ennius fr. 52 Jocelyn. E. fr. $42 I N^{2}$ may refer to the final isolation of Athamas in a dark cave (cf. Lykourgos).

72 See n. 68 above. $C f$. also the Furies escorted off in a torchlit procession at the end of A. Eum. to their dwelling in the earth, where they will be offered wedding sacrifices $(805-6,835,1004)$.

${ }^{73}$ A pollod. Bibl. iii I 5.3; D.S. iv 43; Hygin. Fab. 19; schol. Ov. Ib. 265, 27I. A recent discussion of the myth is by $\mathrm{D}$. Bouvier and $\mathrm{Ph}$. Moreau in RBPhH lxi (1983), 5-i9.

${ }^{74}$ So Winnington-Ingram (see n. 6) I06. That the scholiast on this passage fails to see this, despite knowing other details of the myth, is irrelevant. Kleopatra's imprisonment seems to have been a result of Phineus taking another wife (cf. Antiope, Ino, Philomela), and may in one version have been unto death.

75 This suggests that it is in general not illegitimate to adduce other unmentioned details of these paradigmatic myths. But of. T. C. W. Stinton in Greek tragedy and its legacy: essays presented to $D$. J. Conacher (edd. M. J. Cropp et al., 1986).

${ }^{76}$ The fact that in Soph.'s version it is the stepmother, rather than the father (as in one version), who does the blinding is irrelevant to my argument.

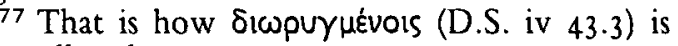
generally taken. 


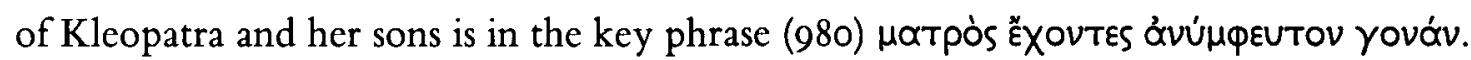
Jebb's translation, 'those sons of a mother hapless in her marriage', is quoted approvingly by Winnington-Ingram, but is in two respects inadequate. Firstly,

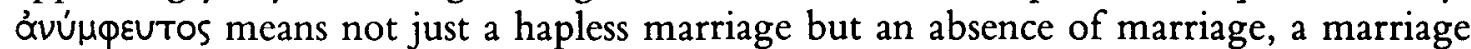
which is no marriage. Kleopatra is assimilated to Antigone and Danae as a woman who suffers a marriage that is no marriage. That then is why the lines on Kleopatra are not about her imprisonment but rather about the caves she dwelt in as an unmarried girl and about her carefree association with her father Boreas. ${ }^{78}$ Secondly, yovó is ambiguous between 'birth' and 'offspring', and so associates with the absence of marriage the sons as well as the mother. The sons are blinded, or imprisoned (perhaps in their mother's tomb): they will not marry. As with Antigone, the failure of the child to marry is associated with the parental marriage that is no marriage: the darkness of blindness or imprisonment surrounds both the last two generations of the line. Similarly Phoinix, after having slept with his father's concubine, is in most versions blinded, but in one (Il ix 453 ff.) doomed by his father's curse to childlessness. It will by now be clear,

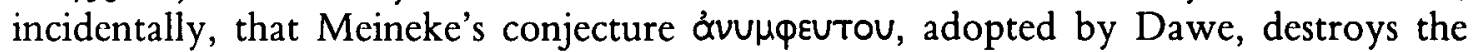
sense of the passage.

Lest my interpretation of this song appear fanciful, let us look at the only other passage of the play in which the imprisonment of Antigone is compared to a myth. Antigone herself, at $823-3 \mathrm{I}$, compares her punishment to the 'subduing' of Niobe by the growth of rock. Niobe is often imagined as transformed into the mountain, but here she is imprisoned by it, as in the Sophoklean Elektra's invocation of Niobe 'in her rocky

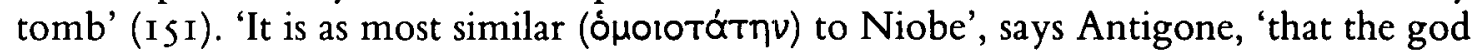
puts me to bed' $(83 \mathrm{I})$. Here again the audience may remember plays on the theme, notably by Aeschylus and Sophokles. In both those lost plays Niobe returned, after the death of her children in Thebes, to her natal family in Sipylos. A papyrus fragment (I 54a) of the Aeschylus tells us of Niobe sitting on a tomb, lamenting the wreck of her marriage, and calling out the name of her father Tantalos, who will come to take her

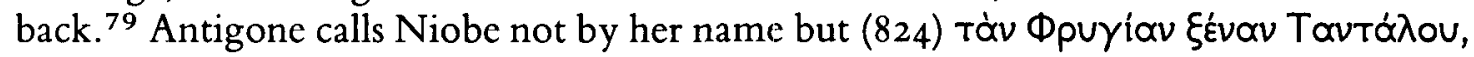
'a Phrygian stranger in Thebes, the daughter of Tantalus'. Once again, the enclosure of a female is associated with her permanent bond with her natal family at the expense of marriage. And I cannot resist adding that in the version of the myth preserved by the fifth century BC Lydian Xanthos ( $F G H 765 F_{20}$ ) Niobe is subjected to the incestuous advances of her father Assaon.

The only element in our complex of themes that we have not yet used to elucidate the Antigone is Dionysos. Dionysos figured in the Lykourgos myth, perhaps also in the myth of the Phineidai: if, as seems likely, Sophokles' lost Tympanistai was about the family of Phineus, then perhaps a Dionysiac chorus of tympanon players witnessed the liberation of Kleopatra from the Thracian cave mentioned in fr. 637. But the liberation of Antigone comes too late. As soon as a repentant Kreon leaves the stage saying that he will free her (I I I2), the chorus sing their famous hymn to Dionysos. Missing from the attempts $^{80}$ to explain this choice of theme has been an understanding of the antithesis between the Dionysiac and the enclosed darkness associated with familial introversion. The Dionysos of this ode is the god of maenadism (I I27-9, I I II-2) and the god of the mountainous periphery (II26 ff.), the god who is to come to purify the city from

\footnotetext{
78 The comparison with a frisky horse $(98 \mathrm{~s})$ is a hymenaial image for the girl to be tamed in marriage.

$79 \mathrm{Cf}$. also Pherekydes FGH 3 F 38 ; Apollod. iii 5.6 'she returns to her father'. Timanthes ap. Eustath. Il. 1343.60 (quoted Radt p. 266) seems to
}

imply that by veiling herself in Aesch. Niobe was choosing a life 'as if belonging to the night or underground'.

${ }_{80}$ Recent attempts are by Winnington-Ingram (see n. 6) I Io-I6, and Segal (see n. 6), 20I-6. 
outside, from over the slope of Parnassos or from across the water (I I4 I-5). He is the god whose worship brings light in the darkness ( I 26-7, I I 47-8, I I I I). This light in the darkness has a mystic significance. Dionysos is associated here with the Eleusinian mysteries (III9-2I). The emphatic last word of the song is "lakXov, the identity of Dionysos in the Eleusinian torchlit all-night celebration, pannychis (I I I I módvvuXol). ${ }^{81}$ In this celebration as represented in Aristophanes' Frogs Iakchos-Dionysos is called 'the

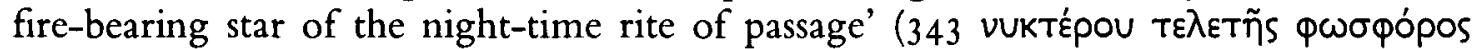
đórńp). Euripides' Ion contains a hymn to Iakchos (IO74 ff.) in which it is said that the starry heaven takes part in the dancing at the Eleusinian pannychis. And so when here in the Antigone the chorus call him 'chorus-leader of fire-breathing stars, who watches over night-time cries' (I I46-8), we may infer that this description derives from his presence at the torchlit dances of the Eleusinian pannychis. ${ }^{82}$ The inference is confirmed by the comment of the scholiast on the passage, that it is according to a mystic formula

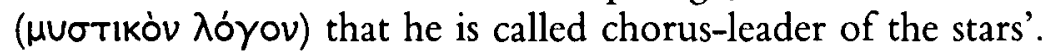

The pannychis was probably preceded by the famous Iakchos procession from Athens. ${ }^{83}$ The day-long procession entered the sanctuary 'together with Iakchos' ${ }^{84}$, for the pannychis. From Christian writing we learn of an all-night search for Kore (Persephone), ended, when she is found, with thanksgiving and tossing of torches. ${ }^{85}$ So too Demeter herself was said to have found her daughter in the Eleusinian sanctuary. ${ }^{86}$ That the torchlit search was ancient is indicated by the archaic Homeric hymn to Demeter, in which, along with other details which certainly reflect the ritual, Demeter searches with torches for her daughter (48). Perhaps then the appeal to Dionysos in the Antigone to come from afar as the torch-bearing Iakchos of the mystic procession implies an analogy between the joyful release of Antigone and of Kore, each from her dark bridal chamber in Hades. The implication would not be lost on an audience who had participated in the unforgettable emotion of the mysteries. The civic function of the Eleusinian and Dionysiac festivals qualifies Dionysos-Iakchos to cure the whole polis of Thebes (II4I-4).87 And just as the release of Antigone from enclosure in her dark bridal-chamber in Hades is in the imagination of the chorus to be celebrated with the mystic light ${ }^{88}$ which celebrated the similar release of Kore, so conversely Lykourgos in the earlier chorus is said to put out the Bacchic fire (964), just as that other imprisoner of women, Pentheus in the Bacchae, in his attempt to imprison Dionysos in the 'darkness' ( 5 Io, 549) of the stables is distracted by a Dionysiac fire, and then the Dionysiac 'light' which signifies salvation for the initiands ${ }^{89}$, both of which he vainly attacks. These associations, and in particular the salvation signified by the mystic light, (for the mysteries do provide that 'escape from Hades' called impossible at 36I-2), make the failure of Antigone to escape from her 'bridal-chamber of Hades' especially devastating. In the subsequent messenger-speech the Eleusinian ritual is evoked again at the very

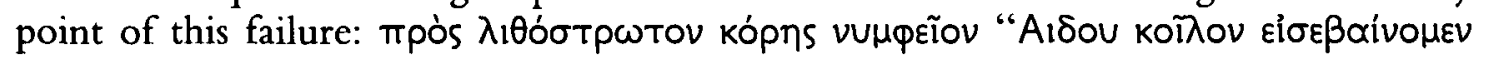

81 On the Dionysiac nature of the procession see e.g. F. Graf, Eleusis und die orphische Dichtung Athens in vorhellenistischer Zeit (I974) SI ff.

82 Winnington-Ingram (see n. 6, I I 3-4) makes much of what he sees as a sinister connotation in the epithet 'fire-breathing'. But this simply derives from the association of stars with the torches in the night-time dance.

${ }_{83} \mathrm{~W}$. Burkert believes (Homo necans, Engl. transl. I983, 277) that the procession followed the path of the searching Demeter.

${ }^{84} \mathrm{~F}$. Sokolowski, Lois sacrées des cités grecques Supplement (Paris 1962) I 5.42. Depiction (?) on the Niinnion tablet (G. E. Mylonas, Eleusis and the
Eleusinian Mysteries (1961), fig. 88).

${ }^{85}$ Lactantius Div. Inst. Epit. I 8 (23). 7; Clem. Alex. Protr. ii I 2.2 (p. I I.20 St.). With the tossing of torches mentioned by Lactantius. of. Ar. Ran. 34 I (of Iakchos).

${ }^{86}$ Ael. Aristid. xix, p. 422 Dindorf (quoted by L. Deubner, Attische Feste 84).

87 Indeed, to restore that civic peace signalled by Dionysiac all-night festivity which the chorus in the parodos desired to follow the end of the fighting (147-54).

88 see G. Thomson on A. Cho. 935-7I.

89 Seaford in CQ xxxi (I98I) $256-7$. 
(I204-S). $\lambda_{1} \theta$ óotp $\omega$ tov means 'paved', which is surprising of Antigone's cave but true of the cave from which Kore may have emerged to create joy at Eleusis. ${ }^{90}$

This view of the symbolic force of the Dionysiac in the myth is confirmed by two other tragedies. In the Phoenician Women (my argument does not depend on the Euripidean authorship of the passages concerned) Antigone emerges from confinement within the interior of the house $(89, \mathrm{I} 94, \mathrm{I} 275-6, \mathrm{I} 636)$. Also confined within the house is the incestuous Oedipus: (64) 'hidden, so that his misfortune may pass from memory'. Antigone in her lament calls herself a 'maenad of the dead' as she casts off her veil; she calls out Oedipus from within, 'you who having cast misty darkness on your eyes (or 'over the house with your eyes') drag out a long life in the house' (1533-5); so that

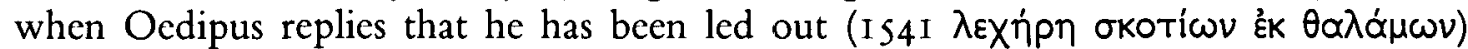
'bedridden, from dark chambers', the 'darkness' seems to belong both to his blindness and to the $\theta \dot{\alpha} \lambda \alpha \mu \mathrm{ol}$. Compare the 'cloud of darkness' of Oedipus' blinding at S. $O T$ I 3 13-4. But my main concern is with the confused ending of the play (from more than one hand, no doubt). ${ }^{91}$ Antigone rejects marriage with Haimon, apparently out of loyalty to her brother, with whom she is prepared to be buried (n. I7 above), then explicitly out of loyalty to her father, with whom, she says, she will die in exile (I657-8I). As father and daughter are about to leave, almost at the very end of the play, Antigone reiterates her desire to bury Polyneikes even at the cost of her own death. ${ }^{92}$ Oedipus replies by telling her to appear to her companions of her age-group (1747) and to go to where Dionysos and the maenads' precinct are in the mountains $(175 \mathrm{I}-3)$. Antigone then refers to her previous maenadism in the mountains, and adds that it won her no favour with the gods. The passage comes oddly in its context. It may well have been misplaced. What does seem clear is that Oedipus is suggesting maenadism as an alternative or antithesis to accompanying him or to dying for Polyneikes.

In Euripides' lost Antigone it seems that Antigone appears on stage as a captive macnad, and that Dionysos himself manifests his power in some way. Moreover, Antigone is married to Haimon, and the eventual entry into Thebes of their son (both on the mountain side) may have been predicted by Dionysos. ${ }^{93}$ The story has been assimilated to the type represented by Antiope. Again, the play exemplifies our polarity between the Dionysiac periphery and enclosed introversion; but here, unlike in Sophokles' Antigone and Euripides' Phoenician Women, it is the Dionysiac that prevails.

I conclude by raising some broad issues which cannot be discussed in detail here. The first is that it may possibly be fruitful to pursue our complex of themes in the psychoanalytic and the anthropological literature. Secondly, although this investigation has been mainly into Greek tragedy, the associations I have been concerned with are a feature of Greek myth as a whole. ${ }^{94}$ It does seem ${ }^{95}$ though that confinement of the female is a theme favoured by tragedy. Why should this be so? Three factors suggest themselves. The first is theatrical space. Tragic action is located between the hidden

90 See e.g. G. E. Mylonas, Eleusis and the Eleusinian mysteries (1961), I 47-9.

91 Sce e.g. D. Conacher in Phoenix xxi (1967), 92-101.

921746 'in the dark I will cover him with earth', reading Hermann's $\sigma$ Kótia.

${ }^{93}$ Hygin. Fab. 72; P. Oxy. 3317; E. fr. $177 \mathrm{~N}^{2}$ (cf. I 78 ); Hypoth. S. Ant. (Aristophanis); R. Scodel in $Z P E{ }_{46}$ (1982) 37-42. G. Xanthakis-Karamanos. in BICS xxxiii ( 1986 ) 107-I I, fails in my view to show that $P$. Oxy. 3317 is not Euripidean, true though it is that the latter part of Hygin. Fab. 72 cannot have been represented (as opposed to prophesied) in Eur's play (pace Scodel; $c f$. fr. 176).
94 To other exx. of apparently undramatised myths mentioned in the footnotes add those of Psamathe (Ov. Ibis 573 f. with schol.) and Leukothoe (Ov. Met. iv 190-255), each buried alive by her father after sex with Apollo.

95 This is no more than a strong impression. In general, a statistical investigation into whether tragedy favours certain themes from the whole body of myth might be rewarding. Other exx. of female captivity not discussed here are from $\mathrm{E}$. Cretans, Protesilaos (? of. Aulus Gellius xii 10.5; E. fr. $648 \mathrm{~N}$ ), Andromeda (Webster, Monuments illustrating traged $\gamma$ and satyr-play 154 f.; Accius fr. $7 \mathrm{I} \mathrm{W)}$. 
inside of the oknvin (house, or sometimes cave) and the equally invisible outside of the city state or the wild. The front of the house separates the public from the domestic, the male world from the interior which belongs in different ways to male and to female. ${ }^{96}$ And so whether the female is to be confined in the house itself, or, as in Antigone, in some place of confinement elsewhere to which she may depart in a bridal or funeral procession, the constant presence of the house front may seem to embody the underlying need or desire of the male to confine the female within the domestic sphere. It is of course, a boundary constantly transgressed. The action of the Bacchae, for example, is structured to an unusual degree around the polarity represented by the exits into the house on the one hand and towards the mountainside on the other. Dionysos has freed the female Thebans from domestic enclosure to the mountainside; Pentheus fails to reenclose them, and he also fails to enclose Dionysos and the Asiatic maenads within domestic space. This polarity is of course characteristic of Dionysiac myth in general. And this brings me to the second factor, which diachronically complements the first. Tragedy originated and continued to be performed in the cult of Dionysos Eleuthereus, the Liberator, who came from distant Eleutherai, where he had presumably freed the 'free females' from which the village derived its name. ${ }^{97}$ Tragic space is particularly appropriate to the complex of Dionysiac myth and ritual in which tragedy originated. The frequency in tragic myth of our complex of themes may then perhaps be explained in part by the Dionysiac origins of tragedy and of tragic space. It cannot of course be the entire explanation. Tragedy was a product of the developing city state. And so a third factor may have been the change brought about by the city-state in the social function of marriage; this is a question I have discussed elsewhere. ${ }^{98}$

\section{University of Exeter}

RICHARD SEAFORD

96 On the gender implications of tragic space see M. Williamson in JACT Reviews iii (1985) I6-20; O. Taplin in Omnibus vii (1984) I3-5; F. Zeitlin in Representations xi (1985) 63-94 (esp. $71-4)$; P. E. Easterling in BICS xxxiv (1988) is-26; cf. H. P. Foley in H. P. Foley (ed.) Reflections of women in antiquity (1981) I27-68; J.-P. Vernant, Myth and thought among the Greeks (Engl. transl., I983), ch. 5.

${ }^{97}$ These may be the daughters of Eleuther there, who, we hear of in a brief notice in Suda (s.v. Meגavalyis), were driven mad by Dionysos.

98 In Euripides, women, and sexuality (ed. Anton Powell, Routledge i989) i s I-76. 